\title{
Profile of hematological abnormalities of Indian HIV infected individuals
}

\author{
Byomakesh Dikshit ${ }^{1}$, Ajay Wanchu*1, Ravinder Kaur Sachdeva ${ }^{1}$, \\ Aman Sharma ${ }^{1}$ and Reena Das ${ }^{2}$
}

\begin{abstract}
Address: ${ }^{1}$ Department of Internal Medicine, Postgraduate Institute of Medical Education \& Research, Chandigarh, India and ${ }^{2}$ Departments of Hematology, Postgraduate Institute of Medical Education \& Research, Chandigarh, India

Email: Byomakesh Dikshit - dikundixit@gmail.com; Ajay Wanchu* - awanchu@yahoo.com;

Ravinder Kaur Sachdeva - drravinderpgi@yahoo.co.in; Aman Sharma - amansharma74@yahoo.com; Reena Das - reenadaspgi@hotmail.com

* Corresponding author
\end{abstract}

Published: 13 August 2009

BMC Blood Disorders 2009, 9:5 doi:10.1 186/147|-2326-9-5

This article is available from: http://www.biomedcentral.com/I47I-2326/9/5

(C) 2009 Dikshit et al; licensee BioMed Central Ltd.

This is an Open Access article distributed under the terms of the Creative Commons Attribution License (http://creativecommons.org/licenses/by/2.0), which permits unrestricted use, distribution, and reproduction in any medium, provided the original work is properly cited.
Received: 7 May 2009

Accepted: 13 August 2009

\begin{abstract}
Background: Hematological abnormalities are a common complication of HIV infection. These abnormalities increase as the disease advances. Bone marrow abnormalities occur in all stages of HIV infection.

Methods: Two hundred HIV infected individual were screened for hematological abnormalities from March 2007-March 2008. Absolute CD4 cell count analysis was carried out by flowcytometry. Depending on the results of the primary screening further investigations were performed, like iron studies, hemolytic work up, PNH work up and bone marrow evaluation. Other investigations included coagulation profile, urine analysis, blood culture (bacterial, fungal, mycobacterial), serology for Epstein Barr virus (EBV), Cytomegalovirus (CMV), Hepatitis B and C, and Parvo BI9 infection.
\end{abstract}

Results: The most common hematological abnormality was anemia, seen in $65.5 \%$ (13I/200) patients. Iron deficiency anemia was seen in $49.2 \%$ (/200) cases while anemia of chronic disease occurred in $50.7 \%$ (/200) cases. Bone marrow evaluation was carried out in 14 patients out of which staging marrow was performed in 2 cases of non-Hodgkin's lymphoma (NHL) and did not show any bone marrow infiltration. In remaining 12 cases bone marrow was done for evaluation of pancytopenia. Among patients with pancytopenia 50\% (6/I2) showed granulomas (4 were positive for AFB, 2 were positive for fungal cryptococci), $25 \%$ (3/I2) showed hemophagocytosis. There was a strong negative correlation between anemia and CD4 counts in this study. Thrombocytopenia was seen in $7 \%(14 / 200)$ cases and had no significant correlation with CD4 counts. No patient had absolute neutrophil count $(\mathrm{ANC})<800$ cells/ $\mu \mathrm{L}$. No case of coagulation abnormalities was found.

Conclusion: Anemia in HIV patients can be a good clinical indicator to predict and access the underlying immune status. Patients should be investigated for hematological manifestations and appropriate steps should be taken to identify and treat the reversible factors. 


\section{Background}

Hematological abnormalities are among the most common complications of HIV. These involve all lineages of blood cells [1]. HIV associated hematological abnormalities seem to be dependent on the level of virus replication, as these abnormalities are severe in late-stage AIDS patients with high viremia. The mechanism underlying these abnormalities is still obscure. A specific diagnosis of the cause and mechanism must be sought because specific treatment may be needed for its correction [1].

Anemia is the most common hematological abnormality in HIV seropositive patients and its incidence is strongly associated with the progression of the disease. Neutropenia is common in the advanced stages of AIDS and often caused or exacerbated by concomitant myelosuppressive drugs. Adverse drug reactions and their complications can cause neutropenia in patients with HIV/AIDS. Thrombocytopenia is correlated with low CD4 cell count and older age [2-4]. Bone marrow abnormalities are found in all stages of HIV disease, increasing in frequency as the disease progresses. A number of characteristic but nonspecific, morphologic abnormalities of the bone marrow of AIDS patients have been reported [5]. Bone marrow examination may be useful for the definitive assessment of iron stores which can assist in the differentiation of iron-deficiency anemia from anemia of chronic disease. There is paucity of data from India on the hematological manifestations of HIV which prompted us to conduct this study. We systematically assessed 200 HIV infected individuals attending immunodeficiency clinic, PGIMER, to look for various hematological manifestations.

\section{Methods}

Two hundred HIV seropositive consecutive individuals were enrolled from the Immunodeficiency Clinic of Internal Medicine Department of Post Graduate Institute of Medical Education \& Research (PGIMER), at Chandigarh between March 2007 to March 2008. Written informed consent was obtained from all. Patients were excluded if they refused to become part of study, were of less than 16 years of age or were pregnant.

Detailed history, general and systemic examination was carried out with emphasis on signs suggesting hematological system involvement like pallor, jaundice, edema, lymphadenopathy, koilonychias, angular cheilitis, glossitis, ecchymosis/purpura, sternal tenderness, hepatosplenomegaly and peripheral neuritis.

The investigations included complete hemogram with peripheral blood picture, complete biochemistry. Depending on the results of the primary screening further investigations were carried out - like iron studies, hemolytic work up, Paroxysmal nocturnal hemoglobinuria
(PNH) work up and bone marrow study. Other investigations included coagulation profile, urine analysis, blood culture (bacterial, fungal, mycobacterial), serology for EBV, CMV, Parvo B19) and viral markers $\left(\mathrm{HB}_{\mathrm{S}} \mathrm{Ag} \&\right.$ Anti $\mathrm{HCV}$ ). Absolute CD4 cell count analysis was carried out by flowcytometry. All 200 patients had been divided into two groups, those having CD4 counts less than 200 cells/ $\mu \mathrm{L}$ (Group 1) and those with CD4 counts more than 200 cells/ $\mu \mathrm{L}$ (Group 2).

Anemia was defined as hemoglobin $<13 \mathrm{~g} / \mathrm{dl}$ (Men) and $<12 \mathrm{~g} / \mathrm{dl}$ (women). Leucopenia was defined as total WBC count less than 4000 cells/ $\mu$ l. Neutropenia was defined as absolute neutrophil count $<1000$ cells/ $\mu$ l. Lymphopenia was considered when absolute lymphocyte count $<800$ cells/ $\mu$ l. Thrombocytopenia was defined as total platelet count $<150 \times 10^{3} / \mu \mathrm{l}[6-8]$.

\section{Bone marrow study}

Bone marrow study was carried out in case of nonresponding anemia, thrombocytopenia, pancytopenia and suspected hematological malignancy. As per indications of bone marrow study, posterior superior iliac spine was the site for bone marrow aspiration and biopsy. Bone marrow smears were stained with May Grunwald'sGeimsa stain and examined by a hematopathologist. Bone marrow samples were carefully evaluated for cellularity, differential counts, dysplastic changes, fibrosis, granulomas, organisms and iron stores. Special stains were done whenever indicated which included cytochemical stains like myeloperoxidase (MPO), periodic acid schiff's (PAS), perl's and leucocyte alkaline phospatase (LAP) stain. Reticulin stain on trephine biopsy was also performed. The bone marrow aspirates were sent for bacterial, fungal and AFB cultures.

\section{Statistical analysis}

Descriptive statistics was expressed as mean \pm SD (Range). Comparisons between data were done by Student's t test and chi-square test. A p value $<0.05$ was taken as statistically significant.

The study was carried out after obtaining permission from the Institute's Ethics Committee.

\section{Results}

The mean age of 200 HIV infected individual was $36.6 \pm$ 8.7 yrs. One hundred eighty seven $(93.5 \%)$ patients were infected due to unprotected heterosexual exposure. About two third of individuals, $67.5 \%(n=135)$ were males and $32.5 \%(n=65)$ were females. One hundred sixty five individuals were symptomatic and 35 were asymptomatic. Symptomatic patients presented with fever $(54.5 \%, \mathrm{n}=$ $90)$, generalized weakness $(18.1 \%, \mathrm{n}=30)$, diarrhea $(10.3 \%, \mathrm{n}=17)$, loss of weight/appetite $(10.3 \%, \mathrm{n}=17)$ 
and others $(6.6 \%, \mathrm{n}=11)$ with non specific symptoms. Out of 165 symptomatic patients, 137 patients had more than one symptom. Table 1 summarizes the results of hematological parameters evaluated in 200 HIV infected individuals. Table 2 shows the comparison between parameters and CD4 counts in asymptomatic and symptomatic groups. Mean CD4 cell count was $202.4 \pm 182$ cells $/ \mu \mathrm{L}$ (range $8-1078$ cells $/ \mu \mathrm{L}$ ). Sixty six individuals (33\%) were receiving ART while 134 (67\%) were not receiving ART.

\section{Laboratory analysis}

Anemia was found in 131 (65.5\%) individuals and iron studies were done in 126 . Of these 131 individuals, $92.3 \%$ $(\mathrm{n}=121)$ were in Group 1, while $7.7 \%(\mathrm{n}=10)$ were in Group 2. Hemoglobin (Hb), Packed cell volume (PCV),
Mean Cell Volume (MCV), Mean corpuscular hemoglobin $(\mathrm{MCH})$, Mean corpuscular hemoglobin concentration $(\mathrm{MCHC})(p<0.001)$ and serum ferritin $(p<0.05)$ showed statistically significant correlation with CD4 counts and other parameters did not have significant correlation with CD4 counts (Table 3 ).

\section{Bone marrow abnormalities}

Out of 200 patients, bone marrow aspiration was carried out in $14(7 \%)$ individuals. Among 14 patients, two patients had non Hodgkin's lymphoma and remaining 12 patients were evaluated for pancytopenia. Six each had $(42.8 \%, \mathrm{n}=6)$ hypocellular marrow and hypercellular marrow while $14.2 \%(\mathrm{n}=2)$ had normocellular marrow $(14.2 \%)$. Among 12 patients with pancytopenia, bone marrow trephine biopsy revealed epithelioid cell granulo-

Table I: Comparison of Baseline parameters in HIV infected males \& females

\begin{tabular}{|c|c|c|c|c|c|}
\hline PARAMETER & $\begin{array}{l}\text { MALE (MEAN } \pm \text { S.D.) } \\
N=135\end{array}$ & $\begin{array}{l}\text { FEMALE } \\
\text { (MEAN } \pm \text { S.D.) } \\
N=65\end{array}$ & $\begin{array}{l}\text { TOTAL } \\
\text { (MEAN } \pm \text { S.D.) } \\
N=200\end{array}$ & $P$ value & $\begin{array}{l}\text { Institute reference } \\
\text { values* }\end{array}$ \\
\hline AGE(yrs) & $37.4 \pm 8.25(18-60)$ & $35.11 \pm 9.66(18-60)$ & $36.66 \pm 8.75(18-60)$ & 0.083 & \\
\hline $\mathrm{Hb}(\mathrm{gm} / \mathrm{dl})$ & $10.58 \pm 2.88(5.1-15.8)$ & $9.8 \pm 2.22(6.2-14.2)$ & $10.3 \pm 2.7(5.1-15.8)$ & 0.081 & $12-18$ \\
\hline PCV\% & $37.8 \pm 7.4(20-68.4)$ & $35.9 \pm 6.7(23.6-46.6)$ & $37.2 \pm 7.2(20-68.4)$ & 0.083 & $36-54$ \\
\hline $\operatorname{MCV}(\mathrm{fl})$ & $81.3 \pm 8.3(62.5-103.3)$ & $77.7 \pm 7.6(62.4-94)$ & $80.1 \pm 8.3(62.4-03.3)$ & 0.003 & $80-96$ \\
\hline $\mathrm{MCH}(\mathrm{pg} /$ cell $)$ & $26.3 \pm 4.3(|8.2-36|)$. & $24.2 \pm 4.1(18.4-32.8)$ & $25.6 \pm 4.4(\mid 8.2-36.1)$ & 0.001 & $27-32$ \\
\hline $\mathrm{MCHC} \%$ & $32.2 \pm 2.7(26.9-38.4)$ & $31 \pm 2.7(26.5-37.0)$ & $31.8 \pm 2.7(26.5-38.4)$ & 0.005 & $30-36$ \\
\hline TLC(cells/ $\mu \mathrm{l})$ & $\begin{array}{l}6985 \pm 2740 \\
(2200-16,000)\end{array}$ & $\begin{array}{l}6715 \pm 2481 \\
(2800-16,000)\end{array}$ & $\begin{array}{l}6898 \pm 2655 \\
(2200-16,000)\end{array}$ & 0.501 & $4000-11000$ \\
\hline ANC(cells/ $\mu \mathrm{l})$ & $4743 \pm 2090(1012-2848)$ & $\begin{array}{l}4743 \pm 2090 \\
(2240-11700)\end{array}$ & $\begin{array}{l}4696 \pm 2052 \\
(1012-12848)\end{array}$ & 0.637 & \\
\hline $\mathrm{ALC}($ cells $/ \mu \mathrm{l})$ & $1778 \pm 740(460-4200)$ & $1722 \pm 676(392-3680)$ & $1759 \pm 719(392-4200)$ & 0.606 & \\
\hline PLATELETS $\left(\times \mid 0^{3} \mu \mathrm{l}\right)$ & $235.1 \pm 105.8(16-685)$ & $249.5 \pm 913.5(13.6-495)$ & $239.8 \pm 101.3(13.6-685)$ & 0.348 & $150-400$ \\
\hline RETIC\% & $\mathrm{I} . \mathrm{I} \pm 0.8(0.4-5.5)$ & $1.2 \pm 0.9(0.4-4.2)$ & $1.17 \pm 0.87(0.5-5.5)$ & 0.318 & $0.2-2.0$ \\
\hline S. IRON( $\mu g / d I)$ & $76.7 \pm 54.2(14-266)$ & $56.1 \pm 46.7(14-223)$ & $69.5 \pm 52.5(14-266)$ & 0.035 & \\
\hline $\operatorname{TIBC}(\mu \mathrm{g} / \mathrm{dl})$ & $396.3 \pm 117.4(155-838)$ & $404.6 \pm 100.2(249-670)$ & $399.2 \pm 111.3(155-838)$ & 0.692 & \\
\hline S. FERRITIN $(\mu g / d l)$ & $522.7 \pm 464.5(10-1500)$ & $232.6 \pm 328.8(5-1420)$ & $421 \pm 443(5-1500)$ & 0.001 & \\
\hline SATURATION\% & $20.3 \pm 14.2(3.1-79)$ & $14.5 \pm 12.7(2.8-72.6)$ & $18.3 \pm 13.9$ & 0.001 & \\
\hline CD4 COUNTS(cells/ $\mu \mathrm{L})$ & $187.2 \pm 15||.(8-785)$ & $233.8 \pm 231.8(19-1078$ & $202.4 \pm 182(8-1078)$ & 0.090 & \\
\hline
\end{tabular}

*Institutional reference values have been provided by a personal Communication with Dr Man Updesh Singh Sachdeva, Department of Hematology, PGIMER, Chandigarh, India. 
Table 2: Comparison between parameters and CD4 counts between asymptomatic and symptomatic groups

\begin{tabular}{|c|c|c|c|c|}
\hline PARAMETERS & $\begin{array}{l}\text { Asymptomatic } \\
(\mathrm{n}=35)\end{array}$ & $\begin{array}{l}\text { Symptomatic } \\
(n=165)\end{array}$ & p value & TOTAL \\
\hline AGE (yrs) & $36.8 \pm 9.6(22-60)$ & $36.6 \pm 8.5(18-60)$ & 0.864 & $36.66 \pm 8.75(18-60)$ \\
\hline BMI & $20.4 \pm 1.8(16-27)$ & $19.6 \pm 1.7(15-27)$ & 0.001 & $20.68 \pm 1.8(15-27)$ \\
\hline $\mathrm{Hb}(\mathrm{gm} / \mathrm{dl})$ & $13.3 \pm 1.5(9.4-15.8)$ & $9.7 \pm 2.4(5.1-14.5)$ & $<0.001$ & $10.3 \pm 2.7(5.1-15.8)$ \\
\hline PCV \% & $43.4 \pm 2.5(38.3-48.6)$ & $35.9 \pm 7.2(20-68.4)$ & $<0.001$ & $37.2 \pm 7.2(20-68.4)$ \\
\hline $\mathrm{MCV}(\mathrm{fl})$ & $85.7 \pm 4.5(67.3-95)$ & $79 \pm 8.4(62.4-103.3)$ & $<0.001$ & $80.1 \pm 8.3(62.4-103.3)$ \\
\hline $\mathrm{MCH}$ (pg/cell) & $28.4 \pm 2.2(18.8-32.6)$ & $25.1 \pm 4.5(18.2-36.1)$ & $<0.001$ & $25.6 \pm 4.4(18.2-36.1)$ \\
\hline $\mathrm{MCHC} \%$ & $33.1 \pm 0.01(27.9-36)$ & $31.5 \pm 0.2(26.5-38.4)$ & 0.002 & $31.8 \pm 2.7(26.5-38.4)$ \\
\hline TLC (cells/ $\mu \mathrm{l})$ & $6560 \pm 1413(4300-10,700)$ & $6969 \pm 2848(2200-16,000)$ & 0.409 & $6898 \pm 2655(2200-6,000)$ \\
\hline ANC (cells/ $\mu \mathrm{l})$ & $4312 \pm 962(2580-5166)$ & $4777 \pm 2209(1012-12848)$ & 0.224 & $4696 \pm 2052(1012-12848)$ \\
\hline ALC (cells/ $\mu \mathrm{l})$ & $1800 \pm 484(1024-2940)$ & $|75| \pm 760(392-4200)$ & 0.713 & $1759 \pm 719(392-4200)$ \\
\hline PLATELETS $\left(\times \mid 0^{3} / \mu \mathrm{l}\right)$ & $248.6 \pm 845.7(150-417)$ & $237.9 \pm 104.6(13.6-685)$ & 0.574 & $239.8 \pm 101.3(13.6-685)$ \\
\hline RETIC \% & $I \pm 0.4(0.5-3.4)$ & $\mathrm{I} . \mathrm{I} \pm 0.9(0.4-5.5)$ & 0.415 & $1.17 \pm 0.87(0.5-5.5)$ \\
\hline S. IRON ( $\mu \mathrm{g} / \mathrm{dl})$ & $64.2 \pm 36.0(33-110)$ & $69.7 \pm 53.0(14-266)$ & 0.839 & $69.5 \pm 52.5(14-266)$ \\
\hline TIBC $(\mu \mathrm{g} / \mathrm{dl})$ & $479.2 \pm 217.7(292-752)$ & $396.6 \pm 106.8(155-838)$ & 0.145 & $399.2 \pm 111.3(155-838)$ \\
\hline S. FERRITIN ( $\mu g / d l)$ & $553.2 \pm 545.3(5-1280)$ & $417 \pm 441.3(5-1500)$ & 0.547 & $421 \pm 443(5-1500)$ \\
\hline CD4 COUNTS (cells/ $\mu$ l) & $386.6 \pm 214.3(65-1078)$ & $163.3 \pm 148(8-967)$ & $<0.001$ & $202.4 \pm 182(8-1078)$ \\
\hline
\end{tabular}

mas in 6 cases ( 4 were positive for AFB, 2 were positive for fungal profiles, morphologically and cytochemically consistent with cryptococci), 3 cases showed hemophagocytosis and 3 cases showed no specific pathology. Staging marrow carried out in two patients with lymphoma (NHL) did not show any infiltration of lymphoma cells.

\section{Discussion and Conclusion}

Hematological complications are a common cause of mortality in HIV infected patients. Cytopenias are most frequent during the advanced stage of disease [1]. We evaluated various hematological manifestations on 200 consecutive HIV seropositive patients who presented to the Immunodeficiency clinic PGIMER, Chandigarh, irrespective of their ART status. We also correlated the final hematological diagnosis of the patients with the CD4 count.

Anemia was the most common presentation. Among 200 individuals, $131(65.5 \%)$ were found to be anemic out of which $4(3 \%)$ cases were in asymptomatic group and 127
$(97 \%)$ were in symptomatic group $(p<0.001)$. Our results on prevalence of anemia showed comparable results with other studies from India [9-11]. In a study by Mir et al on a cohort of $60 \mathrm{HIV}$ infected individuals reported anemia, thrombocytopenia, leucopenia and various permutations of these in majority of individuals [12]. The highest rate of anemia occurs in patients with advanced HIV disease. In our study out of 131 patients, $92.4 \%(n=121)$ cases were those with CD4 counts $<200$ cells $/ \mu \mathrm{L}$, while $7.6 \%(\mathrm{n}=10)$ patients were those with CD 4 counts $>200$ cells $/ \mu \mathrm{L}$ and there was statistically significant difference $(\mathrm{p}<0.001)$ between both the groups. Severe anemia (defined as hemoglobin less than $7.5 \mathrm{gm} /$ dl) was observed in $18.5 \%(n=37)$ patients as compared to $7 \%$ in a study by Kasthuri et al [9].

The cumulative incidence of anemia was highest among patients who had CD 4 lymphocyte count $<200$ cells $/ \mu \mathrm{L}$ and was lowest with CD4 lymphocyte count $>500$ cells/ $\mu \mathrm{L}$, showing an inverse correlation between anemia and 
Table 3: Correlation between parameters and CD4 counts in 200 patients

\begin{tabular}{|c|c|c|c|}
\hline PARAMETER & MEAN \pm S.D & PEARSON CORRELATION & P VALUE \\
\hline AGE (yrs) & $36.66 \pm 8.75(18-60)$ & 0.069 & 0.330 \\
\hline $\mathrm{Hb}(\mathrm{gm} / \mathrm{dl})$ & $10.3 \pm 2.7(5.1-15.8)$ & $0.660 * *$ & $<0.001$ \\
\hline PCV \% & $37.2 \pm 7.2(20-68.4)$ & $0.53 I^{* *}$ & $<0.001$ \\
\hline $\operatorname{MCV}(\mathrm{fl})$ & $80.1 \pm 8.3(62.4-103.3)$ & $0.409 * *$ & $<0.001$ \\
\hline $\mathrm{MCH}$ (pg/cell) & $25.6 \pm 4.4(18.2-36.1)$ & $0.430 * *$ & $<0.001$ \\
\hline $\mathrm{MCHC} \%$ & $31.8 \pm 2.7(26.5-38.4)$ & $0.373^{* *}$ & $<0.001$ \\
\hline TLC (cells/ $/$ l) & $6898 \pm 2655(2200-16,000)$ & 0.004 & 0.952 \\
\hline ANC (cells/ $\mu \mathrm{l})$ & $4696 \pm 2052(1012-12848)$ & -0.018 & 0.802 \\
\hline ALC (cells/ $\mu \mathrm{l})$ & $1759 \pm 719(392-4200)$ & 0.046 & 0.519 \\
\hline PLATELETS $\left(\times \mid 0^{3} \mu \mathrm{l}\right)$ & $239.82 \pm 101.33(13.6-685)$ & 0.135 & 0.056 \\
\hline RETIC \% & $1.17 \pm 0.87(0.5-5.5)$ & -0.059 & 0.404 \\
\hline S. IRON ( $\mu g / d l)$ & $69.5 \pm 52.5(14-266)$ & -0.076 & 0.399 \\
\hline $\operatorname{TIBC}(\mu \mathrm{g} / \mathrm{dl})$ & $399.2 \pm 111.3(155-838)$ & 0.126 & 0.160 \\
\hline S. FERRITIN ( $\mu g / d l)$ & $421 \pm 443(5-1500)$ & $-0.213^{*}$ & 0.016 \\
\hline SATURATION\% & $18.3 \pm 13.9$ & -0.116 & 0.196 \\
\hline CD4 COUNTS (cells/ $\mu \mathrm{l})$ & $202.4 \pm 182(8-1078)$ & 1.0 & \\
\hline
\end{tabular}

CD4 cell count $(\mathrm{p}<0.001)$. HIV infected individuals with anemia are at increased risk for progression to AIDS and mortality, recovery from anemia has been associated with a decreased risk of deaths. We did not estimate the survival in patients with and without anemia, as this was a descriptive study, though the literature clearly indicates that it does affect the survival [13].

The hemoglobin, PCV, MCV, MCH, and MCHC showed statistically significant correlation with CD4 counts ( $\mathrm{p}<$ $0.001)$ in both males and females. Iron studies were done in 126 patients out of which $65.1 \%(\mathrm{n}=82)$ were males and $34.9 \%(n=44)$ were females. Iron deficiency anemia was found in $49.2 \%$ cases ( $\mathrm{n}=62 ; 34$ males, 28 females). Anemia of chronic disease was found in $50.8 \%$ cases $(\mathrm{n}=$ 64; 48 males, 16 females) among which 2 males showed macrocytosis with MCV $>100$, a possibility of coexisting megaloblastic anemia could not be ruled out as serum vitamin B12/folic acid level was not done. Among patients with anemia $25.9 \%(34 / 131)$ males and $21.3 \%$
(28/131) females had iron deficiency anemia, while $36.6 \%(48 / 131)$ males and $12.2 \%$ (16/131) females had anemia of chronic disease. The parameters of iron profile serum iron, TIBC, and saturation were not significantly correlated but the serum ferritin level was significantly correlated to CD4 counts ( $\mathrm{p}<0.05)$. This result was similar to that reported in the study by Semba et al [14].

In this study we did not find any patient with hemolytic anaemia. Viral markers were also performed in anaemic patients None of the infective agents evaluated by serology, including EBV, CMV, Parvo B 19 or Hepatitis B were positive, except for 3 patients positive for Hepatitis C. These 3 patients had CD 4 counts $<200$ cells/ $\mu \mathrm{L}$ and serum ferritin more than $500 \mu \mathrm{g} / \mathrm{dl}$ which suggests anemia of chronic disease.

Thrombocytopenia is known to be a frequent complication of HIV infection $(1,2)$. The mean platelet count in our cohort was $239.8 \pm 101.3 \times 10^{3} / \mu \mathrm{l}$ (range 13.6-685 $\times$ 
$\left.10^{3} / \mu \mathrm{l}\right)$. It had no significant correlation with CD4 counts confirming to the data with the previous study [10]. Prevalence of thrombocytopenia is reported to be higher among persons with AIDS, older persons, homosexuals and injecting drug users [15].

We did not detect any case of neutropenia with ANC of less than 1000 cells $/ \mathrm{mm}^{3}$. The result differ from previous study by Suresh et al in which $22.7 \%$ cases had neutropenia [10]. We also did not find any patient with coagulation abnormalities. Bone marrow examination was carried out in $7 \%(\mathrm{n}=14)$ patients. Among 14 patients, 6 each had hypocellular and hypercellular marrow while 2 patients had a normocellular marrow. The bone marrow trephine biopsy showed epithelioid cell granulomas in 6 patients ( 4 were positive for AFB, 2 were positive for fungal profiles, morphologically and cytochemically consistent with cryptococci). Hemophagocytosis was prominently seen in 3 cases, without evidence of any coinfection. Two patients with lymphoma (NHL) showed no infiltration by lymphoma cells. HIV infection may lead to anemia in different ways; the important causes are defective iron metabolism and reutilization, nutritional deficiencies, opportunistic infections, ART, administration of chemotherapeutic agents and advanced stage of disease with its complications. Therefore, consideration should be given to monitoring anemia in all HIV-positive individuals and to offer supplements like iron preparations, vitamin B12 or folic acid, and in severe cases to provide erythropoietin treatment or blood transfusions, in case indicated.

\section{Competing interests}

The authors declare that they have no competing interests.

\section{Authors' contributions}

BD: Recruited the patients, collected the data, analyzed it and wrote the draft of the manuscript. AW: Conceived the study, supervised the collection of data and revised the draft. RKS: Interpreted the data collected and wrote the draft along with BD. AS: Recruited the patients, analyzed the data and revised the draft. RD: Ensured quality of the laboratory results, reported the bone marrow smears and revised the draft of the manuscript. All authors read and approved the final version of the manuscript.

\section{References}

I. Kirchhoff F, Silvestri G: Is Nef the elusive cause of HIV-associated hematopoietic dysfunction? I Clin Invest 2008, I I 8:1622-5.

2. Sullivan PS, Hanson DL, Chu SY, Jones JL, Ward JW, The Adult/Adolescent Spectrum of Disease Group: Epidemiology of anemia in human immunodeficiency virus (HIV)-infected persons: results from the multistate adult and adolescent spectrum of HIV disease surveillance project. Blood 1998, 91:301-8.

3. Lopaciuk S: Thrombocytopenia associated with HIV infection. Acta Haematol Pol 1993, 24:33-9.
4. Murphy PM, Lane HC, Fauci AS, Gallin Jl: Impairment of neutrophil bactericidal capacity in patients with AIDS. J Infect Dis 1988, 158:627-30.

5. Frontiera M, Myers AM: Peripheral blood and bone marrow abnormalities in the acquired immunodeficiency syndrome. West J Med 1987, I 47:157-60.

6. Werf MJ van der, van Benthem BH, van Ameijden E): Prevalence, incidence and risk factors of anemia in HIV positive persons. Addiction 2000, 95:383-92.

7. Holland SM, Gallin JI: Disorders of Granulocytes and Monocytes, Harrison's Principles of Internal Medicine Volume I. 16th edition. McGraw-Hill Professional; USA; 2004:35I.

8. Cancer Therapy Evaluation Program, Common Terminology Criteria for Adverse Events, Version 3.0, DCTD, NCl, NIH 2006.

9. Kasthuri AS, Sharma S, Kar PK: A study of Hematological Manifestation of HIV. Indian J Sex Transm Dis 2006, 27:9-16.

10. Attili SVS, Singh VP, Rai M, Varma DV, Gulati AK, Sundar S: Hematological profile of HIV patients in relation to immune status - a hospital-based cohort from Varanasi, North India. Turk J Hematol 2008, 25:13-9.

II. Tripathi AK, Kalra P, Misra R, Kumar A, Gupta N: Study of bone marrow abnormalities in patients with HIV disease. JAPI 2005, 53:105-10.

12. Mir N, Costello C, Luckit J, Lindley R: HIV-disease and bone marrow changes: A study of 60 cases. Eur J Hematol I 989, 42:339-43.

13. Mocroft A, Kirk O, Barton SE, Dietrich M, Proenca R, Colebunders R, Pradier C, d Arminio Monforte A, Ledergerber B, Lundgren JD: Anemia is an independent predictive marker for clinical prognosis in HIV infected patients from across Europe. EuroSIDA study group. AIDS 1999, 28:943-50.

14. Semba RD, Shah N, Klein RS, Mayer KH, Schuman P, Vlahov D: Prevalence and cumulative incidence of and risk factors for anemia in a multicenter cohort study of HIV-infected anduninfected women. Clin Infect Dis 2002, 34:260-6.

15. Kouri YH, Borkowsky W, Nardi M, Karpatkin S, Basch RS: Human megakaryocytes have a CD4 molecule capable of binding human immunodeficiency virus-I. Blood 1993, 8I:2664-70.

\section{Pre-publication history}

The pre-publication history for this paper can be accessed here:

http://www.biomedcentral.com/1471-2326/9/5/prepub 